\title{
PENGEMBANGAN PAKET KONTEN BIMBINGAN DAN KONSELING DI SEKOLAH MENENGAH PERTAMA SE KOTA PONTIANAK
}

\author{
Novi Wahyu $\mathbf{H}^{1}$, Hendrik ${ }^{2}$, Toni Elmansyah ${ }^{3}$ \\ ${ }^{1,2,3}$ Program Studi Bimbingan dan Konseling Fakultas Ilmu Pendidikan dan Pengetahuan Sosial, \\ IKIP-PGRI Pontianak, Jalan Ampera No. 88 \\ 1e-mail: opinyasuwarno@gmail.com
}

\begin{abstract}
Abstrak
Pengembangan paket konten merupakan kegiatan penyusunan paket layanan guruguru bimbingan dan konseling. Penyusunan paket layanan ini bertujuan untuk memfasilitasi para guru dan siswa dalam rangka membantu perkembangan dalam setiap aspek pada fase perkembangan siswa. Tujuan dari pengabdian ini adalah:1) memfasilitasi dan menstimulasi perkembangan siswa, 2) Mengatasi hambatan perkembangan siswa pada setiap aspek perkembangan, 3) Menuntaskan ketercapaian tugas perkembangan, 4) Memfasilitasi guru Bimbingan dan Konseling dalam memberikan layanan bimbingan dan konseling. Kegiatan pengabdian telah membantu guru Bimbingan dan Konseling dalam memberikan layanan bagi siswa.
\end{abstract}

Kata Kunci: Penyusunan Paket Konten, Perkembangan Siswa

\section{Abstract}

The development of content packages is an activity of preparing the service package of teachers guidance and counseling. The preparation of this service package aims to facilitate teachers and students in order to foster progress in every aspect of the student development phase. The purpose of this devotion is:1) to facilitate and stimulate student development, 2) Overcoming barriers to student development on every aspect of development, 3) Complete the achievement of the development task, 4) Facilitate teachers in providing counseling and guidance services. The devotional activity has helped teachers of Guidance and Counseling in providing services for students.

Keyword: Preparation of content packages, student progress development

\section{PENDAHULUAN}

Layanan penguasaan konten adalah satu jenis layanan bimbingan dan konseling yang memungkinkan siswa dapat memahami dan mengembangkan sikap dan kebiasaan belajar yang baik, keterampilan dan materi belajar yang cocok dengan kecepatan dan kesulitan belajarnya, serta tuntutan kemampuan yang berguna dalam kehidupan dan perkembangan dirinya. Lebih lanjut Prayitno (2004: 2) menjelaskan layanan penguasaan konten merupakan: Layanan bantuan kepada individu (sendiri-sendiri ataupun kelompok) untuk menguasai kemampuan 
ataupun kompetensi tertentu melalui kegiatan belajar. Menurut Allson, layanan penguasaan konten adalah layanan yang membantu peerta didik menguasai konten tertentu, terutama kompetensi dan atau kebiasaan yang berguna dalam kehidupan disekolah, keluarga atau masyarakat.

Layanan penguasaan konten bertujuan untuk membantu individu menguasi aspek-aspek konten membantu individu menguasai aspek-aspek konten tersebut secara tersinergikan. Dengan penguasaan konten, individu diharapkan mampu memenuhi kebutuhannya serta mengatasi masalah-masalah yang dialaminya.

Jadi layanan penguasaan Konten merupakan layanan BK yang dirancang untuk membantu peserta didik (siswa) dalam menguasai konten tertentu, terutama kompetensi dan kebiasaan dalam melakukan, berbuat atau mengerjakan sesuatu yang berguna dalam kehidupan di sekolah, keluarga, dan masyarakat sesuai dengan tuntutan kemajuan dan berkarakter yang terpuji.

Layanan Penguasaan Konten pada umumnya diselenggarakan secara langsung (bersifat direktif) dan tatap muka, dengan format klasikal, kelompok dan individual. Penyelenggara layanan secara aktif menyajikan bahan, memberikan contoh, merangsang, mendorong dan menggerakkan peserta untuk berpartisipasi aktif mengikuti dan menjalani materi dan kegiatan layanan.

Masa remaja seringkali dihubungkan dengan mitos dan stereotip mengenai penyimpangan dan tidakwajaran. Hal tersebut dapat dilihat dari banyaknya teoriteori perkembangan yang membahas ketidakselarasan, gangguan emosi dan gangguan perilaku sebagai akibat dari tekanan-tekanan yang dialami remaja karena perubahan-perubahan yang terjadi pada dirinya maupun akibat perubahan lingkungan.

Masa remaja dikenal dengan masa pencarian jati diri, dimasa ini terjadi kelabilan anak, bahkan individu memiliki tugas-tugas perkembangan yang harus dipenuhi. Apabila tugas-tugas tersebut berhasil diselesaikan dengan baik, maka akan tercapai kepuasan, kebahagian dan penerimaan dari lingkungan. Keberhasilan individu memenuhi tugas-tugas itu juga akan menentukan keberhasilan individu memenuhi tugas-tugas perkembangan pada fase berikutnya. 
Adapun fenomena akhir abad dua puluh, yaitu berkembangnya kesamaan perlakuan dan harapan terhadap anak-anak dan orang dewasa (Fuhrmann, 1990). Anak-anak masa kini mengalami banjir stres yang datang dari perubahan sosial yang cepat dan membingungkan serta harapan masyarakat yang menginginkan mereka melakukan peran dewasa sebelum mereka masak secara psikologis untuk menghadapinya. Tekanan-tekanan tersebut menimbulkan akibat seperti kegagalan di sekolah, penyalahgunaan obat-obatan, depresi dan bunuh diri, keluhan-keluhan somatik dan kesedihan yang kronis (Santrock, 2012).

Sejalan dengan perubahan-perubahan yang terjadi dalam diri remaja, mereka juga dihadapkan pada tugas-tugas yang berbeda dari tugas pada masa kanak-kanak. Sebagaimana diketahui, dalam setiap fase perkembangan, termasuk pada masa remaja, Manusia lahir membawa potensi yang membutuhkan peran lingkungan untuk membantu pertumbuhan dan perkembangan secara optimal. Masa remaja dikenal dengan masa pencarian jati diri, dimasa ini terjadi kelabilan anak, bahkan individu memiliki tugas-tugas perkembangan yang harus dipenuhi. Apabila tugas-tugas tersebut berhasil diselesaikan dengan baik, maka akan tercapai kepuasan, kebahagian dan penerimaan dari lingkungan. Keberhasilan individu memenuhi tugas-tugas itu juga akan menentukan keberhasilan individu memenuhi tugas-tugas perkembangan pada fase berikutnya

Tugas-tugas perkembangan pada masa remaja yang disertai oleh berkembangnya kapasitas intelektual, stres dan harapan-harapan baru yang dialami remaja membuat mereka mudah mengalami gangguan baik berupa gangguan pikiran, perasaan maupun gangguan perilaku. Stres, kesedihan, kecemasan, kesepian, keraguan pada diri remaja membuat mereka mengambil resiko dengan melakukan kenakalan.

Lebih lanjut dikatakan bahwa masyarakat pada era teknologi maju dewasa ini membutuhkan orang yang sangat kompeten dan trampil untuk mengelola teknologi tersebut. Ketidakmampuan remaja mengikuti perkembangan teknologi yang demikian cepat dapat membuat mereka merasa gagal, malu, kehilangan harga diri, dan mengalami gangguan emosional.Remaja masa kini dihadapkan pada lingkungan dimana segala sesuatu berubah sangat cepat. Mereka dibanjiri 
oleh informasi yang terlalu banyak dan terlalu cepat untuk diserap dan dimengerti. Semuanya terus bertumpuk hingga mencapai apa yang disebut information overload. Akibatnya timbul perasaan terasing, keputusasaan, absurditas, problem identitas dan masalah-masalah yang berhubungan dengan benturan budaya.

Uraian di atas memberikan gambaran betapa majemuknya masalah yang dialami remaja masa kini. Tekanan-tekanan sebagai akibat perkembangan fisiologis pada masa remaja, ditambah dengan tekanan akibat perubahan kondisi sosial budaya serta perkembangan ilmu pengetahuan dan teknologi yang demikian pesat seringkali mengakibatkan timbulnya masalah-masalah psikologis berupa gangguan penyesuaian diri atau ganguan perilaku.

\section{METODE}

Gagasan tentang adanya paket konten berdasarkan asumsi bahwa siswa seyognyanya memiliki konten-konten tertentu berupa seharusnya memiiki seperangkat pengetahuan, keterampilan dan nilai-nilai yang diwujudkan dalam bentuk sikap baik dalam interaksinya dilingkungan keluarga, teman sebaya maupun masyarakat lebih luas. Untuk mewujudkan kondisi tersebut seorang guru Bimbingan dan Konseling seyogyanya memiliki bahan atau materi layanan sebagai panduan dalam memfasilitasi dan menstimulasi perkembangan siswa.

Paket konten dirumuskan dengan menggunakan metode kajian pustaka. Beberapa literatur dikumpulkan, dianalisis dan dipilah sebagai acuan materi paket konten. Materi yang telah dipilah kemudian dirumuskan sebagai portofolio. Selanjutnya materi dalam portofolio tersebut dipelajari dan rumuskan dalam bentuk kerangka konsep penyusunan paket konten.

Perumusan kerangka konsep dan draf paket konten perlu perlu diuji keabsahannya sehingga dalam pelaksanaan penyusunan paket konten dilakukan uji keabsahan melalui forum Focus Group Discassion (FGD). FGD dilaksanakan dalam beberapa sesi dengan menghadirikan peserta PPM, para praktisi, pengamat bahasa dan pengamat perkembangan anak. Keempat pihak ini membahas secara mendalam paket konten yang telah dirumuskan. Pihak inilah nantinya yang akan menyimpulkan Paket Konten layak digunakan atau tidak. 
Metode pelaksanaan kegiatan pengabdian dilakukan dengan mengadopsi Langkah-langkah action research yang terdiri dari 4 (empat) tahapan, yaitu perencanaan, tindakan, observasi, dan refleksi. Kegiatan-kegiatan yang dilakukan pada tahap perencanaan adalah: (1) Sosialisasi program pengabdian pada sekolah mitra terutama Musyawarah Guru Bimbingan dan Konseling (MGBK) (2) Pertemuan tim pelaksana pengabdian dengan MGBK; dan (3) Penyusunan program pelatihan.

Selanjutnya dilakukan tindakan berupa implementasi program pelatihan. Pada saat pelaksanaan tindakan dilakukan observasi. Observasi dilakukan selama proses perumusan konten berbasis tugas-tugas perkembangan siswa dengan menggunakan acuan standar kompetensi kemandirian peserta didik (SKKPD) oleh para guru mitra. Instrumen yang digunakan berupa catatan lapangan. Beberapa hal yang diobservasi adalah kendala-kendala dan kelemahan-kelemahan yang muncul dalam memberikan layanan yang sesuai dengan perkembangan siswa. Tahap terakhir adalah refleksi. Hal-hal yang dilakukan dalam tahap refleksi adalah: (1) Mengevaluasi kendala-kendala dan kelemahan-kelemahan yang muncul dalam penggunaan media pembelajaran matematika pada penerapan pembelajaran di kelas; dan (2) Hasil evaluasi digunakan untuk memperbaiki kekurangankekurangan yang ada paket konten.

\section{HASIL DAN PEMBAHASAN}

Kegiatan dilaksanakan dalam bentuk workshop dan diskusi (focus group discussion (FGD)). Workshop dilaksanakan di AULA IKIP PGRI Pontianak pada hari Sabtu tanggal 03 Februari 2018. Peserta workshop dibagi dalam beberapa kelompok, dengan tujuan setiap kelompok membahas dan merumuskan peta konsep. Peta konsep yang dirumuskan kemudian dikembangkan menjadi rumusan kompetensi dasar dan standar kompetensi yang diharapkan. Berdasarkan kompetensi dasar dan standar kompetensi yang dirumuskan, peserta kelompok selanjutnya mengembangkan teori sebagimana konten yang diharapkan.

Secara teknis pelaksanaan pengembangan paket konten bimbingan dan konseling di sekolah mencakup: (1) 
1. Acara pembukaan workshop

Pada kegiatan dilakukan pada hari Sabtu, 03 Februari 2018 bertempat di Aula Hadari Nawawi Lantai 4 Gedung Rektorat IKIP-PGRI Pontianak. Peserta kegiatan adalah guru BK yang tergabung pada MGBK SMP Maupun SMA se Kota Pontianak dan se Kabupaten Kubu Raya.

2. Penyampaian materi Workshop

Penyampaian materi oleh dosen Bimbingan dan Konseling yakni Martin, M. Pd. Materi yang disampaikan berupa panduan dalam membuat konten yang sesuai dengan tugas tugas perkembangan siswa.

3. Sesi Tanya jawab

Setelah penyampaian materi, maka dilakukan sesi tanya jawab antara peserta dan penyaji. Dalam diskusi dua arah tersebut dimaksudkan untuk lebih menggali lebih dalam pemahaman peserta agar penyusunan paket konten sesuai dengan peruntukannya.

4. Workshop kegiatan (dibagi dalam beberapa kelompok)

Kegiatan selanjutnya adalah workshop. Pada kegiatan ini peserta dibagi dalam dua kelompok besar, yakni kelompok guru SMA dan kelompok guru SMP. Kedua kelompok tersebut dibagi lagi menjadi beberapa kelompok lagi untuk membahas beberapa konten sesuai dengan materi perkembangan siswa. Adapun rincian kegiatan sebagai berikut:

a. Masing-masing kelompok merumuskan peta konsep paket konten

b. Masing-masing kelompok merumuskan kompetensi dasar dan standar kompetensi paket konten

c. Masing-masing kelompok mengembangkan materi paket konten berdasarkan standar kompetensi dasar dan standar kompetensi yang telah dirumuskan.

5. Pembahasan internal draf paket konten

Setelah penyusunan draf dilakukan, maka dilakukan pembahasan internal antar kelompok. Hal ini dilakukan agar setiap anggota dapat saling memberikan masukan agar konten yang dirumuskan sesuai dengan perkembangan siswa. 
6. Melaksanakan Focus Group Discassion (FGD) dengan guru Bimbingan dan Konseling bersama personel MGBK Pontianak Kota.

Tahapan kegiatan pengabdian terdiri dari empat tahapan, yaitu perencanan, tindakan, observasi, dan refleksi. Kegiatan pertama yang dilakukan pada tahapan perencanaan yang melibatkan anggota tim pelaksana PKM. Dalam perencanaan tersebut anggota tim membahas permasalahan terkait waktu, tempat, serta biaya. Selain itu pembagian tugas (job description) dilakukan agar kegiatan berjalan dengan efektif dan efisien. Selanjutnya adalah sosialisasi program PKM pada mitra yaitu MGBK Kota Pontianak dan MGBK Kubu Raya. Sosialisasi dilakukan dalam bentu koordinasi dengan ketua masing MGBK.

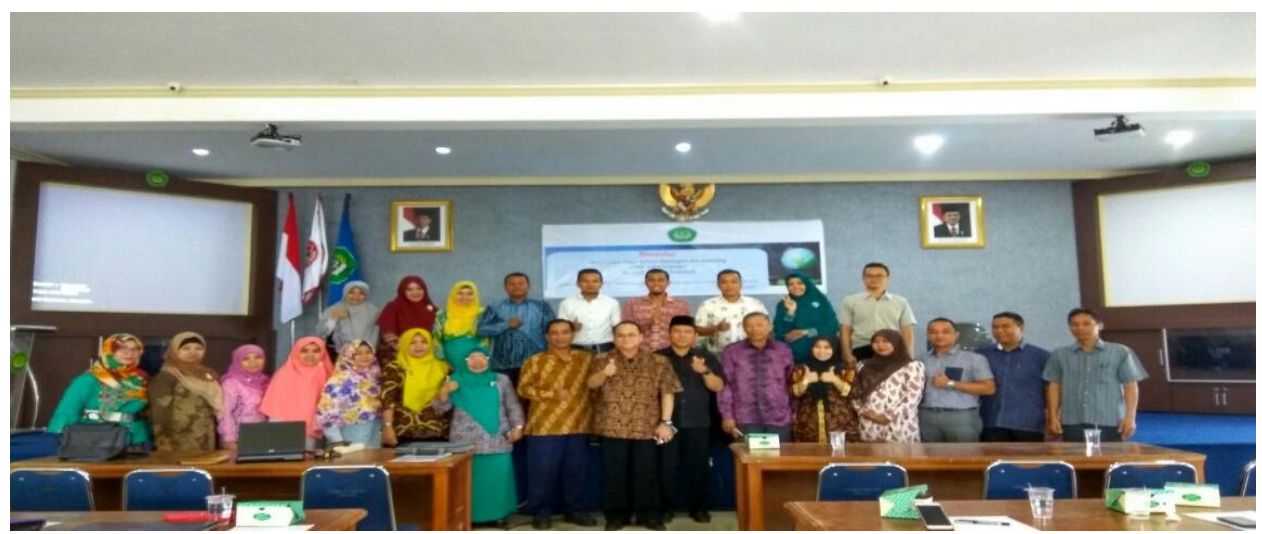

Gambar 1. Acara Pembukaan kegiatan workshop

Kegiatan kedua adalah pelaksanaan kegiatan. Kegiatan dilaksanakan dalam bentuk workshop dan diskusi (focus group discussion (FGD)). Workshop dilaksanakan di AULA IKIP PGRI Pontianak pada hari Sabtu tanggal 03 Februari 2018. Peserta workshop dibagi dalam beberapa kelompok, dengan tujuan setiap kelompok membahas dan merumuskan peta konsep. Peta konsep yang dirumuskan kemudian dikembangkan menjadi rumusan kompetensi dasar dan standar kompetensi yang diharapkan. Berdasarkan kompetensi dasar dan standar kompetensi yang dirumuskan, peserta kelompok selanjutnya mengembangkan teori sebagimana konten yang diharapkan.

Penyusunan paket layanan ini bertujuan untuk memfasilitasi para guru dan siswa dalam rangka membantu perkembangan dalam setiap aspek pada fase 
perkembangan siswa. Berikut tujuan dari pengembangan paket konten bimbingan dan konseling disekolah:

1. Memfasilitasi dan menstimulasi perkembangan siswa.

2. Mengatasi hambatan perkembangan siswa pada setiap aspek perkembangan.

3. Menuntaskan ketercapaian tugas perkembangan.

4. Memfasilitasi guru Bimbingan dan Konseling dalam memberikan layanan bimbingan dan konseling.

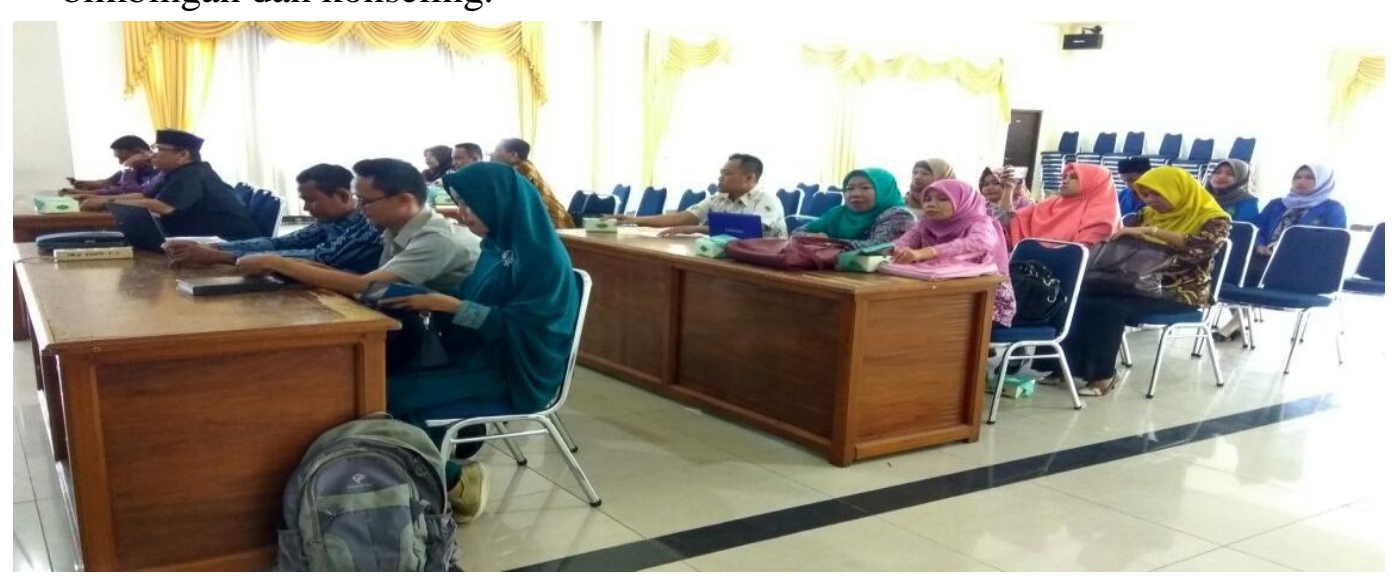

Gambar 2. Pelaksanaan Kegiatan (Diskusi)

Adapun hasil dari kegiatan workshop penyusunan paket konten adalah Secara umum PPM program studi Bimbingan dan Konseling IKIP PGRI Pontianak tahun tahun akademik 2016-2017 semester 2 dalam bentuk kegiatan workshop penyusunan paket konten bimbingan dan konseling diskolah berjalan dengan lancar. Secara khusus hasil yang dicapai adalah sebagai berikut; 1) seluruh peserta workshop memahami tujuan akhir dari penyusunan paket konten, baik terhadap diri sebagai guru bimbingan dan konseling maupun terhadap siswa, 2) seluruh peserta secara antusias dalam mengikuti workshop, kondisi ini dapat dilihat dari ketepatan waktu kehadiran hingga selesai kegiatan, dan banyaknya peserta yang bertanya, 3) masing-masing kelompok aktif bekerja dalam merumuskan tugas sebagaimana yang telah diberikan, 4) masing-masing kelompok menyelesaikan tugas yang diberikan setelah kegiatan workshop selesai, 5) tersusunnya kerangka modul paket konten yang belum masih memerlukan penyempurnaan lebih lanjut. 
Pelaksanaan kegiatan tersebut menemui beberapa kendala diantaranya 1) penyusunan paket konten sangat membutuhkan waktu dan konsentrasi yang memadai, sehingga waktu workshop yang satu hari kurang memadai untuk menyelesaikan tugas sebagaimana diberikan kepada peserta,2) ditemukan beberapa kasus pada peserta yang membutuhkan pendampingan disebabkan keraguan kebenaran kompetensi dasar dan standar kompetensi yang telah dirumuskan.

Anggaran pelaksanaan Pengabdian pada Masyarakat tentang workshop penyusunan paket konten bimbingan dan konseling sepenuhnya dibiayai oleh IKIP PGRI Pontianak, yang dalam hal ini dikelola oleh unit Penelitian dan Pengabdian Pada Masyarakan (P3M) IKIP PGRI Pontianak.

\section{SIMPULAN}

Secara umum PPM program studi Bimbingan dan Konseling IKIP PGRI Pontianak tahun tahun akademik 2016-2017 semseter 2 dalam bentuk kegiatan worhshop penyusunan paket konten bimbingan dan konseling disekolah berjalan dengan lancar. Tidak ditemukan kendala yang secara signifikan mempengaruhi tujuan dari kegiatan. Hasil yang dicapai yaitu dirumuskannya Standar kompetensi dan kompetensi dasar yang akan akan menjadi dasar dikembangkankannya materi paket konten bimbingan dan konseling.

Secara khusus hasil dari kegiatan PKM adalah sebagai berikut: (1) kegiatan penyusunan paket konten Bimbingan dan Konseling sangat perlu dilakukan hal ini karena guru BK belum mempunyai panduan yang jelas dalam memberikan layanan yang seseuai dengan perkembangan siswa, (2) kegiatan ini perlu dilakukan kembali dnegan membahsa topic-topik yang lebih spesifik yang sesuai dengan karakter daerah masing-masing peserta didik.

Adapun saran yang diharapkan adalah lembaga Penelitian dan Pengabdian Pada Masyarakat (P3M) IKIP PGRI Pontianak memberikan kesempatan kepada peserta PPm untuk melanjutkan sampai pada tahap tersusunnya Paket Konten Bimbngan dan Konseling. Selnjutnya diharapkan kepada peserta PPM lebih maksimal untuk melakukan pendampingan penyusunan paket konten. 


\section{UCAPAN TERIMA KASIH}

Terima kasih diucapkan kepada IKIP PGRI Pontianak atas dana Pengabdian kepada MAsyarakat tahun anggaran 2018 yang diberikan dan MGBK Kota Pontianak dan Kabupaten Kubu Raya.

\section{DAFTAR PUSTAKA}

Prayitno.2004. Dasar-Dasar Bimbingan dan Konseling. Rineka Cipta: Bandung.

Santrock, John W. 2012. Life-span Development Perkembangan Masa Hidup edisi 13. Erlangga: Jakarta.

Fuhrmann, Barbara S.(1990) Adolescene, Adolets. Second Edition, Scoot Foresman and Company. Illionis. 